\title{
Analisis Lama Penggunaan Komputer Pada Mahasiswa Universitas ABC Dengan Metode Algoritma C4.5
}

\author{
Wida Pesah Sucihermayanti ${ }^{1)}$, Daniel Tunggono Saputro ${ }^{2)}$, \\ Grace Gabriella Herald ${ }^{3}$, Yeremia Chris Saragi ${ }^{4)}$ \\ ${ }^{1}$ Program Studi Teknik Informatika Universitas AKI Semarang, ${ }^{2}$ Program Studi Teknik Informatika \\ Universitas AKI Semarang, ${ }^{3}$ Program Studi Teknik Informatika Universitas AKI Semarang, \\ ${ }^{4}$ Program Studi Teknik Informatika Universitas AKI Semarang \\ 1222180009@ student.unaki.ac.id, ${ }^{2}$ daniel.tunggono@unaki.ac.id, ${ }^{3}$ \\ 222180013@student.unaki.ac.id, ${ }^{4} 222180016 @$ student.unaki.ac.id
}

\begin{abstract}
Nowadays computers are a very important technology and widely used, almost in all sectors of the field, one of which is in the field of education. In ABC University we know that every student must have or even used a computer often. For this reason, the authors make research on the duration of computer use in students and anything that can affect the duration of students in using computers. Using the C4.5 Algorithm the author created a decision tree where the decision tree is made from datasets that have been collected from several students who filled out the questioner. Then the dataset calculation results will provide a rule or scheme where students can be said to have used a computer for a long time or not. For example, students in the last semester or semester 8 can be said to be using a computer for a long time.
\end{abstract}

Keyword : Computer, Algorithm c4.5, Data Mining, Decision Tree

\begin{abstract}
Abstrak
Pada masa sekarang ini komputer merupakan Teknologi yang sangat penting dan banyak digunakan, hampir disemua sektor bidang, salah-satunya dalam bidang pendidikan. Dalam Universitas ABC kita mengetahui bahwa setiap mahasiswa pastinya pernah atau bahkan sering menggunakan komputer. Untuk itu penulis membuat penelitian mengenai Lama penggunaan komputer pada mahasiswa serta apa saja yang dapat mempengaruhi mahasiswa dalam Lama penggunaan komputer. Dengan Menggunakan Algoritma C4.5 penulis membuat sebuah pohon keputusan (Decision Tree) dimana Pohon keputusan ini dibuat dari dataset yang telah dikumpulkan dari beberapa mahasiswa yang mengisi angket. Lalu hasil perhitungan dataset akan memberikan sebuah rule atau pola dimana mahasiswa dapat dikatakan Lama menggunakan Komputer atau tidak. Seperti mahasiswa semester akhir atau 8 dapat dikatakan Lama menggunakan komputer.
\end{abstract}

Kata kunci : Komputer, Algoritma C4.5, Data Mining, Pohon Keputusan

\section{PENDAHULUAN}

Perkembangan Teknologi saat ini sangatlah pesat, bahkan penggunaan komputer sudah tidak asing lagi bagi kita, karena setiap pekerjaan sudah melibatkan komputer untuk mempermudah kita menyelesaikan pekerjaan tersebut.

Penggunaan komputer sudah diberlakukan di berbagai sektor untuk mempermudah pekerjaan yang dilakukan oleh manusia seperti Pendidikan pemerintahan , dan lain-lain. Kanitkar, K., Carlson juga pernah menulis bahwa $75 \%$ pekerjaan di seluruh dunia menggunakan komputer. Oleh sebab itu penggunaan komputer sudah menjadi bagian dari masyarakat bahkan sebagian waktu masyarakat dilakukan di depan komputer .

Lama penggunaan komputer oleh manusia beragam-ragam ada yang lama menggunakan komputer dan ada juga yang tidak lama menggunakan komputer. Berdasarkan jurnal yang ditulis oleh Azkadina, lama bekerja di depan komputer berhubungan secara signifikan dengan kejadian CVS (Computer Vision Syndrome) dan bekerja di depan komputer selama lebih dari atau sama dengan 4 jam secara terus- 
menerus berisiko tiga setengah kali lipat lebih tinggi untuk mengalami CVS dibandingkan dengan bekerja di depan komputer selama kurang dari 4 jam secara terus-menerus.

Universitas $\mathrm{ABC}$ adalah salah satu universitas berbasis komputer dimana mahasiswa diwajibkan bisa mengoperasikan komputer. Setiap mahasiswa memiliki lama waktu yang berbeda dalam menggunakan komputer. Ada mahasiswa yang menggunakan komputer yang tergolong lama atau lebih dari 4 jam sehari dan ada juga mahasiswa menggunakan komputer yang tergolong tidak lama atau dibawah dari 4 jam sehari.

Dalam kasus tersebut peneliti akhirnya memiliki rasa ingin tahu untuk mengetahui lama atau tidak lamanya penggunaan komputer oleh mahasiswa di Universitas ABC.

\section{METODE PENELITIAN}

Penelitian ini dilakukan dengan mencari dan mengumpulkan data yang ada di lapangan dan survei yang telah dilaksanakan dengan maksud untuk mencari tahu data-data yang dapat mempengaruhi lama penggunaan komputer. Populasi adalah seluruh mahasiswa di Universitas ABC yang menggunakan komputer desktop atau laptop. Penelitian ini dilakukan dengan beberapa tahap sebagai berikut:

\section{a. Perumusan masalah}

Penelitian ini dimulai dengan dilakukan perumusan terhadap masalah yang akan digunakan dalam topik penelitian. Pada tahap ini juga penulis akan menentukan konsep seperti apa yang dibutuhkan dan juga informasi yang diperlukan.

\section{b. Studi Literatur}

Tahap ini adalah Tahap untuk mencari Literatur untuk mendapatkan informasi yang berhubungan dengan topik penelitian dari berbagai sumber seperti jurnal, buku, dan artikel.

\section{c. Menyiapkan Instrument \\ Pada tahap ini dilakukan persiapan terhadap instrument yang akan digunakan dengan Menyusun instrument penelitian.}

\section{d. Mengumpulkan Data}

Setelah persiapan diatas selesai maka selanjutnya dilakukan pengumpulan data dengan cara menyebarkan kuesioner kepada responden.

\section{e. Mengolah dan Menganalisis Data}

Tahap ini dilakukan pengolahan data yang diperoleh dari penyebaran kuesioner sebelumnya. Selanjutnya dilakukan analisis data dengan menggunakan metode statistik. Metode yang akan digunakan adalah metode decision tree yang diolah menggunakan Algoritma C4.5.

\section{f. Mengolah dan Menganalisis Data}

Tahap ini dilakukan pengolahan data yang diperoleh dari penyebaran kuesioner sebelumnya. Selanjutnya dilakukan analisis data dengan menggunakan metode statistik. Metode yang akan digunakan adalah metode decision tree yang diolah menggunakan Algoritma C4.5.

\section{g. Perumusan Kesimpulan}

Tahap terakhir dalam penelitian ini adalah merumuskan kesimpulan. Menarik kesimpulan dilakukan setelah menguji hipotesis dan mengetahui hubungan antar variabel yang satu dengan yang lainnya. Kesimpulan yang didapat merupakan jawaban dari pertanyaan dalam penelitian.

\section{TINJAUAN PUSTAKA}

Penelitian ini dilakukan dengan Untuk itu peneliti menggunakan salah satu algoritma dari data mining yaitu algoritma $\mathrm{C} 4.5$ untuk menggolongkan mahasiswa yang lama atau tidak lama dalam menggunakan komputer.

\section{a. Data Mining}

Data mining merupakan ilmu yang digunakan untuk mengolah informasi dan sekumpulan data yang memanfaatkan kecerdasan dalam membangun pola-pola untuk mengenali karakteristik dari data. Salah satu teknik data mining klasifikasi yang dapat mengatasi masalah seperti ini adalah Algoritma c4.5.

\section{b. Algoritma C4.5}

Merupakan pengembangan dari algoritma ID3 (Iterative Dichotomiser 3) yang memiliki keuntungan yaitu mudah dimengerti 
dan bisa divisualisasikan ke dalam bentuk pohon keputusan (Decision Tree). Algoritma C4.5 merupakan algoritma yang sering digunakan dalam pemecahan suatu masalah dan pengambilan keputusan dalam sebuah organisasi, instansi maupun lembaga.

\section{c. Decision Tree}

Pohon keputusan atau decision tree adalah model visual untuk menyederhanakan proses pembuatan keputusan secara rasional. Metode pohon keputusan mengubah fakta yang sangat besar menjadi pohon keputusan yang merepresentasikan aturan. Pohon keputusan juga berguna untuk mengeksplorasi data, menemukan hubungan tersembunyi antara sejumlah calon variabel input dengan sebuah variabel target. Metode ini cukup efektif untuk menganalisis data yang memiliki atribut banyak dan mudah untuk dimengerti oleh pengguna.

\section{HASIL DAN PEMBAHASAN}

Setelah melakukan Survei menggunakan angket yang disebarkan melalui Google form kepada Mahasiswa di Universitas ABC dengan mengajukan beberapa pertanyaan seputar lama penggunaan komputer. Pertanyaan yang kami ajukan antara lain, Jenis Kelamin, Status, Umur, Semester dan Jurusan. Dengan pertanyaan tersebut kami mendapat sampel sebanyak 60 Responden pada Universitas ABC.

Dari data 60 responden yang ada kami mengolah data tersebut dan mendapatkan hasil untuk mahasiswa berumur 15-19 ada 7 orang, umur 20-24 ada 49 orang, dan umur 25-30 ada 4 orang. Sedangkan dari segi jenis kelamin untuk Pria ada 14 orang dan perempuan ada 46 orang. Lalu untuk status dibagi menjadi 2 yaitu mahasiswa saja atau mahasiswa sambil bekerja untuk mahasiswa terdapat 45 orang dan mahasiswa dengan bekerja ada 15 orang. untuk fakultas terdapat 5 yaitu TI ada 18 orang, Ekonomi ada 14 orang, psikologi ada 12 orang, kesehatan ada 14 orang, dan terakhir ada bahasa 2 orang. Dan yang terakhir yaitu semester, dikarenakan penelitian dilakukan pada masa semester genap maka semester diambil dari semester 2 ada 12 orang, semester 4 ada 9 orang, semester 6 ada 37 orang dan semester 8 ada 2 orang.
Dari data yang didapat kami olah menjadi sebuah dataset yang dapat dihitung menggunakan Algoritma C4.5 dengan mencari entropy, Gain dan Information Gain dari data menggunakan formula:

$$
\operatorname{Entropy}(s)=\sum_{i=1}^{n}-p i * \log \log 2 p i
$$

Dengan :

$\mathrm{S}$ = ruang (data) sampel yang digunakan untuk training.

$\mathrm{Pi}=$ proporsi dari Si terhadap S. diperoleh dari Gain.

$$
\operatorname{Gain}(S, A)=\operatorname{Entropy}(S)
$$

$$
-\sum_{i=1} \frac{|S i|}{|S|} \operatorname{Entropy}(S i)
$$

Dengan :

$\mathrm{S}=$ ruang (data)

$\mathrm{A}=$ atribut

$\mathrm{V}=$ nilai

$\operatorname{Nilai}(\mathrm{A})=$ himpunan

$|\mathrm{Si}|=$ jumlah sampel untuk nilai i

$|\mathrm{S}|=$ jumlah seluruh sampel data

Entropy $(\mathrm{Si})=$ entropy untuk sampel $\mathrm{i}$

$$
\operatorname{SplitInfo}(S, A)=-\sum_{i=1} \frac{S i}{S} \log 2 \frac{S i}{S}
$$

Dengan :

$\mathrm{Si}=$ jumlah sampel untuk atribut $\mathrm{i}$

Dengan :

$$
\operatorname{GainRatio}(S, A)=\frac{\operatorname{Gain}(S, A)}{\operatorname{SplitInfo}(S, A)}
$$

Gain $(\mathrm{S}, \mathrm{A})=$ information gain pada atribut $\mathrm{A}$.

Maka diperoleh Hasil :

Untuk Entropy Total:

Tabel 1. Entropy Total

\begin{tabular}{|l|c|c|c|c|}
\hline Atribut & $\begin{array}{l}\text { Jumla } \\
\mathrm{h}\end{array}$ & $\begin{array}{l}\text { LAM } \\
\text { A }\end{array}$ & $\begin{array}{l}\text { TIDA } \\
\text { K } \\
\text { LAM } \\
\text { A }\end{array}$ & $\begin{array}{l}\text { ENT } \\
\text { ROP } \\
\text { Y }\end{array}$ \\
\hline $\begin{array}{l}\text { TOTA } \\
\text { L }\end{array}$ & 60 & 37 & 23 & $\begin{array}{l}0 \\
960\end{array}$ \\
\hline
\end{tabular}

Entropy $=((-E 74 / C 74) * I M L O G 2(E 74 / C 74)+(-$ F74/C74)*IMLOG2(F74/C74))

*menggunakan Excel

Mengetahui Entropy, information gain, split ratio, dan gain ratio pada masing-masing atribut. Dari tabel dapat dilihat bahwa gain tertinggi terdapat di fakultas maka Fakultas 
Jurnal Informa : Jurnal Penelitian dan Pengabdian Masyarakat. p-ISSN : 2442-7942, e-ISSN 2716-5051

Volume 7 Nomor 1 Juni 2021

akan menjadi Node pertama atau akar dari Pohon Keputusan.

Berdasarkan Perhitungan yang di dapat maka akan membentuk pohon keputusan sebagai berikut : Dengan Rule yang didapat yaitu :
Fakultas = Bahasa

| Jenis Kelamin = PRIA: Tidak Lama

\begin{tabular}{|c|c|c|c|c|c|}
\hline Atribut & Macam & Entropy & Information Gain & Split Info & Gain ratio \\
\hline \multirow{3}{*}{$\begin{array}{l}\text { Jenis } \\
\text { kelamin }\end{array}$} & & & 0,009 & 0,784 & 0,0 \\
\hline & Pria & 0,863 & & & \\
\hline & Wanita & 0,978 & & & \\
\hline \multirow[t]{3}{*}{ Status } & & & 0,007 & 0,811 & 0,009 \\
\hline & Mahasiswa & 0,939 & & & \\
\hline & $\mathrm{M}+\mathrm{B}$ & 0,997 & & & \\
\hline \multirow[t]{4}{*}{ Umur } & & & 0,005 & 0,861 & 0,005 \\
\hline & $20-24$ & 0,963 & & & \\
\hline & $25-30$ & 0,811 & & & \\
\hline & $15-19$ & 0,985 & & & \\
\hline \multirow[t]{6}{*}{ Fakultas } & & & 0,109 & 2,117 & 0,052 \\
\hline & TI & 0,650 & & & \\
\hline & Ekonomi & 0,985 & & & \\
\hline & Psikologi & 1 & & & \\
\hline & Kesehatan & 0,890 & & & \\
\hline & Bahasa & 1 & & & \\
\hline \multirow[t]{5}{*}{ sem } & & & 0,022 & 1,469 & 0,015 \\
\hline & 2 & 0,980 & & & \\
\hline & 4 & 0,991 & & & \\
\hline & 6 & 0,909 & & & \\
\hline & 8 & 1 & & & \\
\hline
\end{tabular}

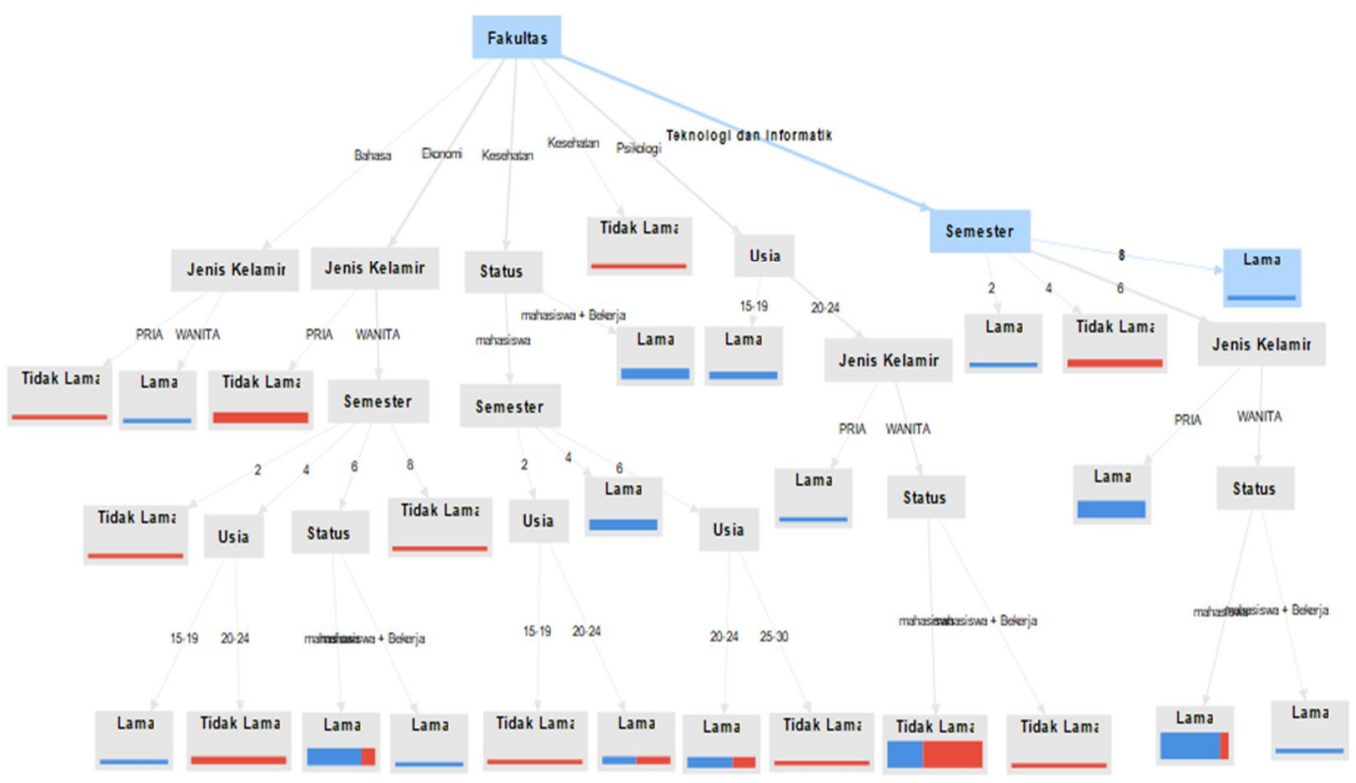

Gambar 1 Hasil Pohon Keputusan dari RapidMiner 

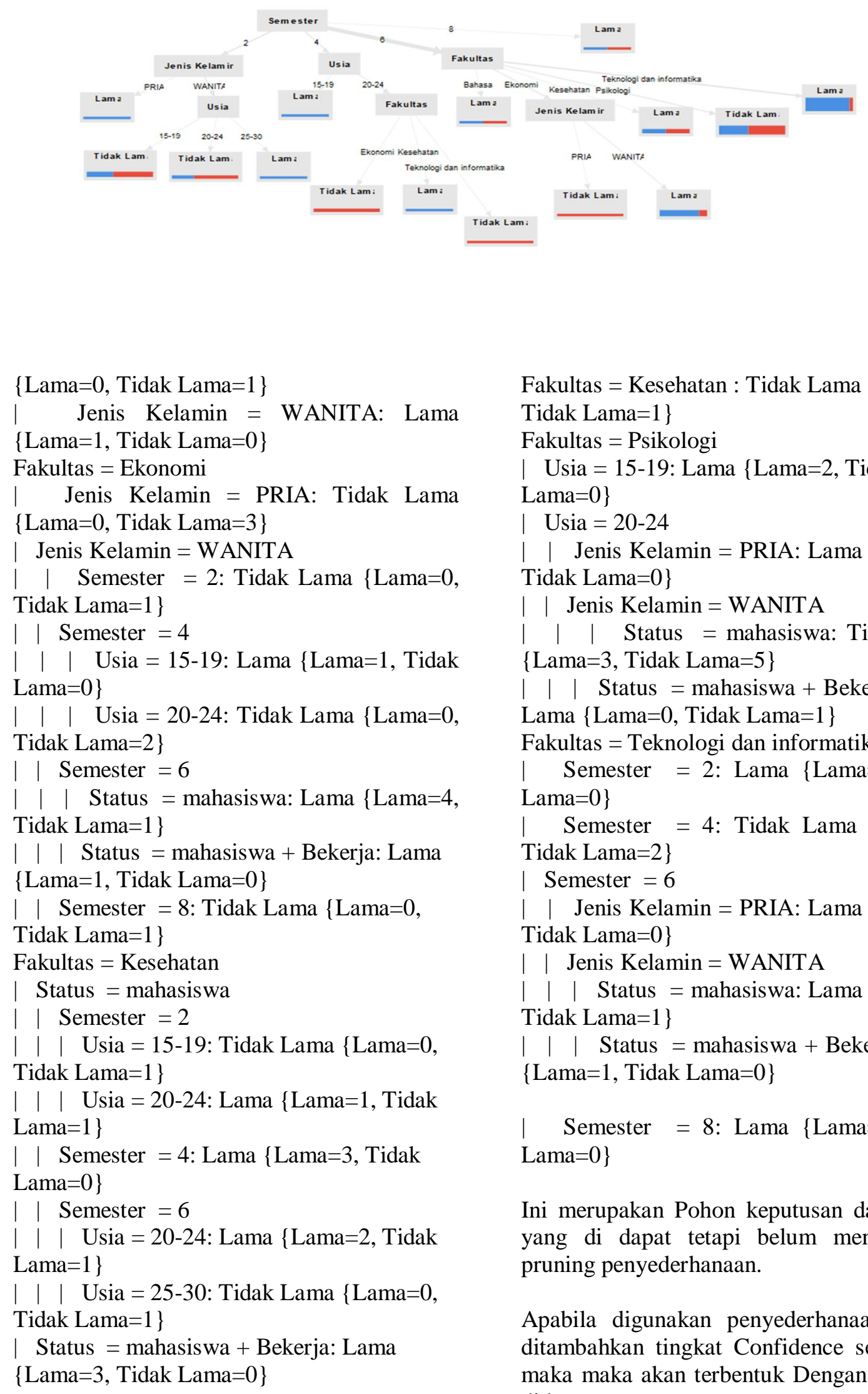

Fakultas $=$ Kesehatan $:$ Tidak Lama $\{$ Lama $=0$, Tidak Lama $=1\}$

Fakultas $=$ Psikologi

Usia $=15-19:$ Lama $\{$ Lama=2, Tidak

Lama $=0\}$

Usia $=20-24$

| | Jenis Kelamin $=$ PRIA: Lama $\{$ Lama $=1$,

Tidak Lama $=0\}$

| $\mid$ Jenis Kelamin = WANITA

| $\mid$ | Status = mahasiswa: Tidak Lama

$\{$ Lama $=3$, Tidak Lama $=5\}$

| | | Status = mahasiswa + Bekerja: Tidak

Lama $\{$ Lama $=0$, Tidak Lama $=1\}$

Fakultas $=$ Teknologi dan informatika

| Semester $=2$ : Lama $\{$ Lama $=1$, Tidak Lama $=0\}$

| Semester = 4: Tidak Lama $\{$ Lama $=0$, Tidak Lama $=2\}$

Semester $=6$

| | Jenis Kelamin = PRIA: Lama $\{$ Lama $=5$, Tidak Lama $=0\}$

| | Jenis Kelamin = WANITA

| | | Status = mahasiswa: Lama $\{$ Lama=7, Tidak Lama $=1\}$

| | | Status = mahasiswa + Bekerja: Lama $\{$ Lama $=1$, Tidak Lama $=0\}$

| Semester = 8: Lama $\{$ Lama $=1$, Tidak Lama $=0\}$

Ini merupakan Pohon keputusan dari dataset yang di dapat tetapi belum menggunakan pruning penyederhanaan.

Apabila digunakan penyederhanaan dengan ditambahkan tingkat Confidence sebesar 0,1 maka maka akan terbentuk Dengan rule yang didapat: 


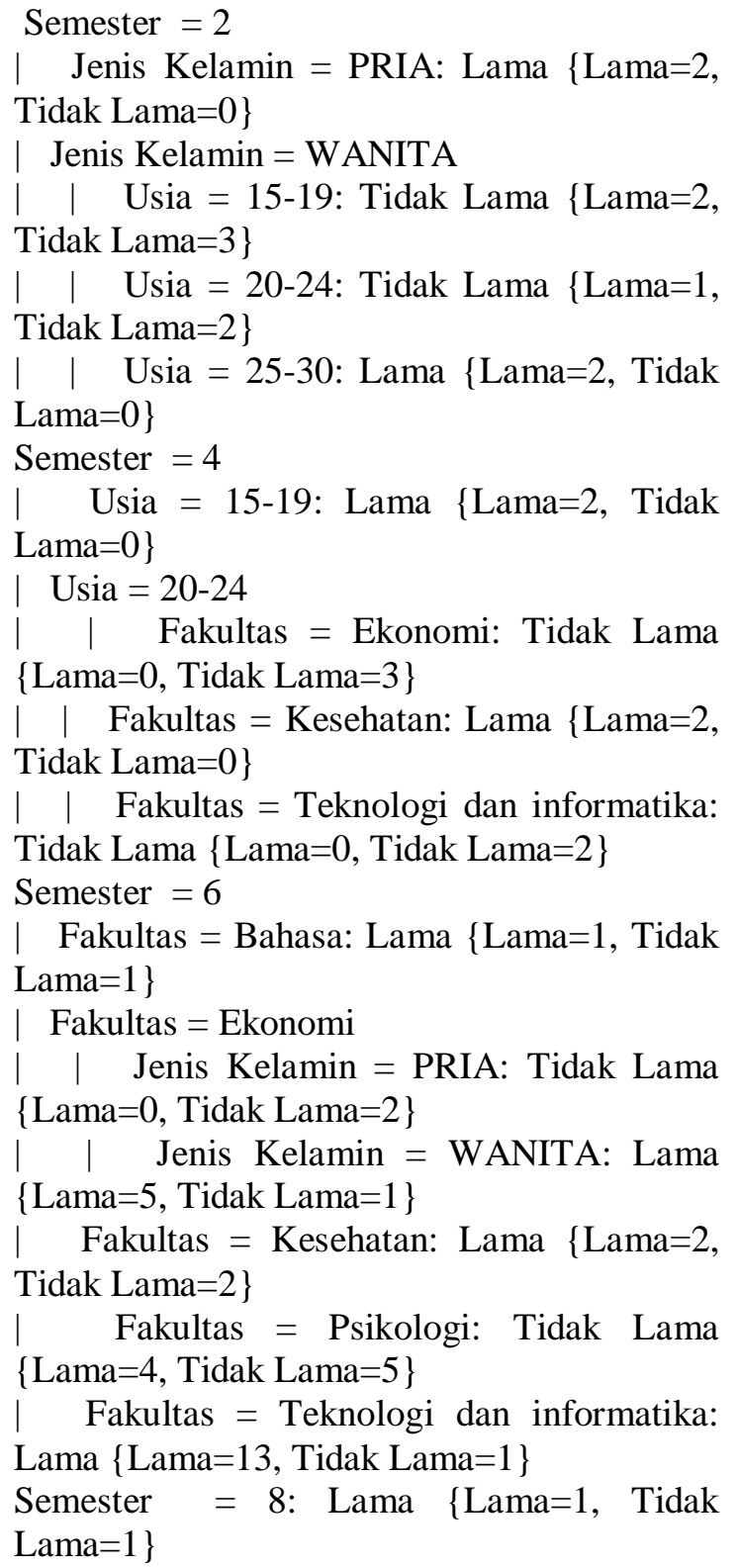

\section{KESIMPULAN}

Maka didapatkan kesimpulan dari hasil perhitungan dan dari Pohon Keputusan bahwa Lama penggunaan Komputer dapat dilihat dari jenis kelamin, umur, fakultas, status dan semester seorang mahasiswa. Tetapi hal tersebut tidak dapat dijadikan Tolak Ukur yang Pasti karena begitu kompleksnya tetapi dapat menghasilkan sebuah Rule dimana:

1) Apabila mahasiswa tersebut sedang menduduki semester akhir / semester 8 keatas maka ia akan cenderung Lama menggunakan Komputer

2) Untuk yang semester 2 apabila ia berjenis kelamin Pria maka ia akan Lama menggunakan komputer sedangkan untuk wanita semester 2 di umur dibawah 24 lebih tidak Lama menggunakan komputer. Dan jika umur diatas itu dan memiliki pekerjaan cenderung Lama menggunakan komputer.

3) Apabila mahasiswa berada di semester 4 di lihat dari usia, dan untuk usia 20-24 maka harus melihat dari fakultas mana untuk dapat menentukan Lama dan tidaknya.

4) Pada semester 6 mahasiswa dilihat dari fakultasnya. Untuk TI cenderung Lama. Sedangkan Ekonomi dilihat lagi dari segi Jenis Kelamin.

Dari penjabaran tersebut penulis mengetahui bahwa dataset yang diolah menggunakan Algoritma C4.5 dapat menghasilkan aturan yang dimana keterlibatan fakultas, jenis kelamin, umur, status dan semester dapat berpengaruh dalam lamanya seorang mahasiswa menggunakan komputer.

\section{REFERENSI}

Kanitkar, K., Carlson, A.N., Yee, R. "Ocular Problems Associated with Computer Use": Review of Ophthalmology.http://www.revophth.c om/contentd/features/i/1317/c/25354/, 11 Juli 2013.

Azkadina, A yang berjudul "Hubungan Antara Faktor Risiko Individual Dan Komputer Terhadap Kejadian Computer Vision Syndrome", laporan hasil karya ilmial UNDIP, 2021

Adinugroho, Sigit., Arum, Yuita. 2018. Implementasi Data Mining Menggunakan Weka. Surabaya: UB Press

Rufiyanto, Anief., Rochcham, Muhammad., Rohman, Abdul. 2020. Penerapan Algoritma C4.5 Untuk Prediksi Kepuasan Mahasiswa. 2020. Sleman: Deepublish.

Siswanto. 2007. Operation Research. Jakarta : Erlangga.

Achmad, Budanis Dwi Meilani, Fauzi Slamat, and Fakultas Teknologi Informasi ITATS Yang Berjudul "Klasifikasi data karyawan untuk menentukan jadwal kerja menggunakan metode decision tree", Jurnal Publikasi Dosen ITATS, 19 Juni 2013, Surabaya.

Kusrini. 2009. Algoritma Data Mining. Yogyakarta: Andi Offset. 